CUPALIAM 21, 1994, Pp. 9-34

\title{
ALGUNAS REFLEXIONES SOBRE EL FIN DE TARTESSOS EN LA CUENCA MEDIA DEL GUADIANA: LA CRISIS DEL CUATROCIENTOS Y EL DESARROLLO DE LA BETURIA ${ }^{1}$
}

\author{
ALONSO RODRÍGUEZ DIAZ \\ Universidad de Extremadura
}

\section{Resumen}

El presente estudio trata de abordar los problemas del fin de Tartessos a partir de los resultados arqueológicos obtenidos durante los últimos años en uno de sus ámbitos periféricos más personalizados: el Valle Medio del Guadiana. En momentos tan confusos, comienzan a comprenderse mejor acontecimientos tan relevantes para esta zona como la destrucción de Cancho Roano y la definición de la Beturia prerromana. Además, este trabajo pretende ser complementario al titulado "El Valle Medio del Guadiana, espacio de frontera en la protohistoria del Suroeste $\left(\mathrm{I}^{-1}\right.$ (Saguntum 27. 1994).

\section{Resumê}

La présente étude essaie denvisager les problèmes de la fin de Tartessos à partir des résultats archéologiques des dernières années dans l'une des étendues périphériques les plus personnalisées: la vallée moyenne du Guadiana. Dans un moment si confus, nous commençons à mieux comprendre dés événements aussi importants pour cette zone que le sont la destruction de Cancho Roano et la définition de la Beturia pré-romaine. Par ailleurs, ce travail prétend être complementaire à celui intitulé "La Vallée Moyenne du Guadiana, un espace de frontière dans la protohistoire du Sudoest (1)" (Saguntum 27. 1994).

Desde hace algún tiempo la investigación arqueológica viene interrogándose sobre los múltiples factores que intervinieron en la caída de Tartessos y los orígenes del complejo panorama etnocultural posterior recogido en los textos. Sin embargo, las importantes lagunas que ofrece el registro arqueológico sobre estos confusos momentos e incluso

${ }^{1}$ El presente trabajo se inscribe en el Proyecto de la DGICYT (PB93-0415) "Paleoambiente y paleoeconomia durante el ler. milenio a. C. en Extremadura". 
el carácter secundario que dichas cuestiones han tenido respecto a otras no menos interesantes del propio ámbito tartésico impiden actualmente que poseamos una visión coherente y fluida de la segunda mitad del Ier. milenio a. C. en todo el Suroeste peninsular. Pero, además, lícito es reconocer que consciente o inconscientemente, dichas deficiencias - si así pueden ser definidas- en no pocos casos han tratado de superarse mediante la supervaloración y prolongación de determinados acontecimientos o episodios críticos que nos convierten a un tiempo en cómplices y víctimas de controvertidas situaciones. Probablemente, el más claro y anecdótico reflejo de éstas sea el babelismo terminológico generado por la utilización simultánea en un mismo territorio de expresiones como "Orientalizante Final o Tardío", "Postorientalizante", "Ibérico Antiguo" o "Turdetano Inicial" para designar un mismo período.

Con la prudencia que impone el estado actual de la investigación protohistórica en Extremadura, el objetivo del presente trabajo es precisamente abordar estas cuestiones desde la proximidad distante del Guadiana Medio, cuyo carácter periférico y fronterizo en la paleogeográfía tartésico-turdetana parece incuestionable (Almagro Gorbea, 1977; Maluquer de Motes, 1981; Aubet Semmler, 1990; Celestino y otros, 1992; Rodríguez Díaz, 1994). Como es de sobra conocido y sin infravalorar la amplia serie de hallazgos orientalizantes extremeños, Medellín y Cancho Roano continúan siendo los enclaves que aportan la base documental principal para el estudio de este período y, al mismo tiempo, constituyen los mejores ejemplos de una historiografía reciente abocada inexcusablemente a suscitar constantes hipótesis y replanteamientos sobre unos mismos datos. Por otra parte, no resulta menos sabido, que el fin de Tartessos en el Valle Medio del Guadiana conllevó un importante retroceso de sus vínculos seculares con el Guadalquivir y que las consecuencias culturales más relevantes de todo ello, a corto-medio plazo, se resumen en un notable proceso de "continentalización" o "celtización" de las tradiciones y tecnologías orientalizantes. Fue precisamente en ese contexto de cambio y continuidad cultural en el que surgió el nuevo espacio geográfico y socioeconómico que, ya en época romana, los autores grecolatinos identificaron como "Baeturia" y situaron entre el Guadiana y el Guadalquivir (García Iglesias, 1971; Rodríguez Díaz, 1989 y 1990; Berrocal Rangel, 1992; Canto, 1991 y 1995).

En este sentido, podemos concretar que los resultados obtenidos en estos anos sobre la protohistoria reciente bajoextremena (todavía parciales en muchos casos y por tanto no definitivos) permiten esbozar de momento tres grandes fases o etapas a lo largo de los últimos siglos del Ier. milenio a. C. Un primer momento especialmente oscuro y complejo se desarrollaría "grosso modo" entre el último tercio del siglo vı y comienzos del IV a. C. y culturalmente marcaría el declive del horizonte orientalizante y los comienzos de la II Edad del Hierro. Una segunda etapa, comprendida entre el siglo IV y fines del III a. C., estaría definida por el máximo desarrollo de los "castros" y la plena configuración de la "Beturia prerromana" en torno al Guadiana Medio. Y, finalmente, a este segundo período sucedería otro que supondría, por una parte, el declive del anterior y, por otra, el contacto con el mundo romano; su cronología podría situarse entre los siglos II-1 a. C. y fines del I d. C. Será a lo largo de esta etapa cuando surja el nuevo pa- 
norama poblacional gestionado desde los denominados "oppida" de la Beturia clásica, auténticos pilares del proceso romanizador posterior. Dado que de los dos últimos horizontes nos hemos ocupado en varios trabajos recientes (Rodríguez Díaz, 1993, 1994 y 1995 a-c), nuestra atención en éste se centrará preferentemente en el primero de ellos: el que nos sitúa justamente ante el fin de Tartessos y los confusos orígenes de la "Beturia prerromana". Con todo ello, sólo pretendemos comprender algo más de qué forma tan relevante la posición geográfica de este espacio de tránsito entre el "Norte y el Sur" ha sido un condicionante de primer orden en su desarrollo histórico-cultural.

\section{SOBRE EL OCASO DE TARTESSOS Y LA “CRISIS DEL CUATROCIENTOS”}

En el Suroeste peninsular y más concretamente en las áreas núcleares tartésicas, es admitido entre quienes se ocupan con mayor profundidad de este tema que estos siglos son bastante confusos y difíciles, por cuanto en dicho segmento temporal se inicia la recuperación de las consecuencias de la crisis del siglo VI a. C. y por ende de la caída de Tartessos. Como es bien conocido, el último tercio del siglo vi a. C. constituyó una fase de verdadera recesión económica en la que intervinieron de una forma encadenada y más o menos directa acontecimientos tan relevantes y significativos como la caída de Tiro, la inestabilidad de las relaciones tartesio-fenicias, Alalia y el tratado romano-cartaginés del 509, entre otros. Arqueológicamente, dicho período crítico se constata esencialmente a través del retroceso de la minería y el ocaso del comercio foceo (Fernández Jurado, 1986; Cabrera Bonet, 1988-89), la reducción o el abandono de hábitats como El Carambolo (Carriazo, 1973) e incendios generalizados en Carmona (Carriazo y Raddatz, 1960; Pellicer y Amores, 1985), Lebrija (Caro y otros, 1986), Ategua (Blanco Freijeiro, 1983) y la Colina de los Quemados (Luzón y Ruiz, 1973). No obstante, de igual modo hay que admitir que, por razones diversas, en algunos asentamientos estos aspectos negativos no se registran con tanta intensidad (Ruiz Mata, 1986, 243; Belén y Escacena, 1990; Escacena Carrasco, 1993), lo cual, a su vez y en nuestra opinión, podría cuestionar el carácter determinante de estos años de recesión en la desaparición definitiva del modelo económico tartésico. Sea como fuere, todo parece indicar que, en el plano económico y ya durante todo el siglo v a. C., comienza a gestarse en torno a Gadir un replanteamiento profundo de los vectores económicos tradicionales de dicho territorio (Ruiz Mata, 1986 y 1987; Fernández Jurado, 1987-a) y desde el punto de vista cultural se asiste a un tiempo al declive prolongado del mundo orientalizante y a la génesis del horizonte turdetano, cuya identidad y significación no deja de plantear controversias (Escacena Carrasco, 1987 y 1989; Belén y Escacena, 1992).

Como es fácil imaginar, no estamos aún en condiciones de calibrar desde una perspectiva estrictamente arqueológica los efectos reales de la referida crisis inicial tartésica en la Cuenca Media del Guadiana ni tan siquiera a través de sus enclaves más emblemáticos: Medellín y Cancho Roano. Tan solo recientemente, se ha argumentado en este sentido la posibilidad de relacionar con la referida recesión del siglo vı a. C. el nivel de des- 
trucción registrado en el estrato IV de la Cata Este del Teatro (Almagro Gorbea, 1977, 527). Como se recordará, dicho estrato, detectado también en la Cata 2 excavada durante la campaña de 1991 (Almagro y Martín, 1994, 112-113), está formado por una tierra arcillosa de color anaranjado y se considera en su conjunto como los restos de una gran construcción de adobe - quizá una muralla-destruida hacia el 525 a. C. Por su parte y ante la falta de datos arqueológicos firmes sobre esta cuestión en Zalamea de la Serena, sugerimos como simple hipótesis de trabajo que con todo ello podrían relacionarse las causas que determinaron la ruina del edificio antiguo de Cancho Roano (ya detectado por Maluquer y corroborado por las más recientes excavaciones) y, en consecuencia, las razones del posible cambio socioeconómico o religioso que obligaron a reconstruir a finales del siglo $\mathrm{VI}$ a. C., con un significado social acorde con los sistemas de poder que vertebran el Mundo Ibérico (Almagro Gorbea y otros, 1990; Almagro Gorbea, 1993) pero con la misma esencia comercial de sus comienzos (Celestino Pérez, 1992), el complejo arquitectónico que vemos actualmente. En suma y como ya intuyera Maluquer (1981), todo parece indicar que a partir de este período se consolida en nuestra región un tipo de asentamiento que capitaliza la gestión de la tierra dentro de un panorama general en el que aún resulta muy difícil explicar con fluidez qué tipo de relación existió entre estos centros y los poblados en alto ocupados desde el Bronce Final. Aunque con insistencia se viene considerando a Medellín (integrado en esta última categoría de asentamientos) como un gran "oppidum", exponente de la evolución hacia fórmulas de organización sociocultural y territorial próximas a las del sur peninsular, la realidad arqueológica de otros lugares recientemente excavados como la Sierra del Risco (Sierra de Fuentes, Cáceres) aconseja hacer lecturas más pausadas sobre estas cuestiones y, por consiguiente, de aspectos como la aculturación o la diversidad poblacional de esta tardía fase orientalizante (Rodríguez Díaz, 1994: Enríquez y otros, e.p.)

Fuera de un modo u otro, pero sin perder de vista en ningún momento las particularidades que Cancho Roano introduce en el poblamiento de estos siglos en el Guadiana Medio, lo cierto es que el horizonte cultural que dicho edificio representa nos sitúa - con los problemas terminológicos e interpretativos que ello plantea- en una etapa de clara continuidad con el Período Orientalizante, justamente cuando en todo el Mediterráneo Occidental se asiste "a la transición de la fase fenicia a la fase púnica" (Aubet Semmler, 1987, 276) y en el sur peninsular comienzan a consolidarse los grandes "oppida" ibéricos y turdetanos (Ruiz y Molinos, 1993; Aubet Semmler, 1995).

Aunque parece claro que a lo largo del siglo $\mathrm{v}$ a. C. los circuitos comerciales se reconducen en función de los nuevos focos socioculturales emergentes, el registro arqueológico recuperado en el visible y monumentalizado complejo de Zalamea evidencia que. dentro de la autonomía de gestión de recursos admitida para este "palacio-santuario", nuestra región se mantuvo durante esta fase preferentemente vinculada al sur peninsular a través de los mismos canales y estímulos que siglos antes caracterizaran la fase antigua del Orientalizante Extremeño. De este modo lo reflejan los objetos de adorno y bronces, los platos grises de borde reforzado al interior, las cerámicas pintadas y de barniz rojo, los alabastros (Celestino y Jiménez, 1993), las importaciones áticas (Fer- 
nández Jurado, 1987-a; Cabrera, 1987 y 1994) y la propia producción anfórica con paralelos directos en el Cerro Macareno, La Cabeza, Carmona, Doña Blanca o Tejada la Vieja (Guerrero Ayuso, 1991). En este sentido, Celestino Pérez (1992, 30-31) no duda en subrayar "la componente púnica de los objetos de lujo aparecidos en este lugar, pudiendo haber sido ese comercio el que introdujera los objetos de procedencia egipcia, etrusca o suritálica. Asímismo, cabe destacar la presencia exclusiva de ánforas de tradición fenicio-púnica. Todos estos materiales sólo se verán superados, sin duda en un momento postrero, por las importaciones griegas, basadas exclusivamente en los vasos cerámicos de lujo".

En función de todo ello, con frecuencia se trata de vincular la reactivación de la periferia tartésica en general, y del sector extremeno en particular, con la llegada de grupos procedentes del fenecido mundo tartésico (Celestino Pérez, 1992; Aubet Semmler, 1990; Fernández Jurado, 1988-89). Sin embargo y aparte de la constatación en Cancho Roano de una amplia secuencia constructiva que confirma su origen mucho antes, a nuestro juicio, dicha reactivación no parece ser otra cosa más que el fiel reflejo de que la etapa crítica del siglo VI no determinó - como parece suceder también en la propia Andalucía Occidental- el fin súbito y traumático de un modelo económico gestado a lo largo de varios siglos, basado en un abanico de posibilidades económicas más amplio probablemente del que hasta ahora la investigación ha valorado y sostenido por un tupido entramado de rutas comerciales que entrelazaban el Suroeste peninsular. Por ello, más que a través de movimientos migratorios siempre difíciles de concretar a partir del registro arqueológico, el "fenómeno periférico" quizá pudo estar en relación con una fase de recuperación y relanzamiento de los circuitos interiores preexistentes, como respuesta del propio sistema a la práctica desaparición de la redes comerciales que unían el Suroeste peninsular con el Mediterráneo Oriental, su reconducción hacia la órbita cartaginesa y la formación de una estructura de poder paralela a los estados ibéricos. En este contexto, hemos de convenir que resulta más fácil comprender no sólo ya la comentada reedificación y monumentalización del propio Cancho Roano, sino también la expansión y la prosperidad que durante el siglo $\mathrm{v}$ alcanza la práctica totalidad de los asentamientos bajoandaluces.

Así, para Cádiz-Doña Blanca dicho siglo supone "un resurgimiento de la ciudad adquiriendo una estructura regulada en calles e ínsulas. Los tipos cerámicos evolucionan hacia las formas clásicas turdetanas, manteniéndose siempre determinadas formas orientalizantes (...) Todo ello parece probar que la crisis económica que azotó a Tartessos desde fines del siglo vi a. C. no tuvo repercusiones considerables en el área gaditana" (Ruiz Mata, 1986, 243; Blanco y Corzo, 1981; Perdigones y otros, 1990). Fernández Jurado, 1987-b, 182) afirma que "entrado el siglo $\mathrm{V}$ a. C., Tejada se nos vuelve a mostrar como un importante y recuperado núcleo poblacional". Algo similar parece ocurrir en Huelva (Belén y otros, 1977, 370). En Niebla, Belén y Escacena (1990, 237) no dudan que la crisis minera del siglo VI a. C. afectara a este asentamiento, pero es evidente que "no supuso su final (...) y a partir del siglo $\mathrm{v}$ a. C. documentan una actividad constructiva importante". Pellicer $(1993,196)$ se sorprende de "que a partir del 500 a. C., según el 
Cerro Macareno, aumente el comercio durante todo el siglo $\mathrm{v}$ a. C., atendiendo al alto porcentaje de ánforas siendo de destacar las púnicas y algunas corintias, efecto de transacciones con Corinto, de donde se importaría aceite o vino y a donde se exportarían cereales y salazones". Igualmente M. E. Aubet muestra una cierta extraneza ante el el hecho de que Setefilla quedara deshabitada "después de un momento floreciente y de pleno desarrollo cultural durante el siglo v a. C." (Aubet y otros, 1983, 108). Finalmente, Chaves y De la Bandera $(1988,373)$ reconocen que en Montemolín el "Ibérico Inicial" "marca un indudable momento de apogeo y desarrollo en el poblado". Etcétera. Pero además, cabe resaltar para concluir que, a pesar de las innovaciones y renovaciones tecnológicas que este nuevo período comporta (en especial las cerámicas áticas en sus momentos finales), los restos materiales de estos asentamientos no suponen una ruptura en el proceso de la cultura material orientalizante. Más bien dichos hallazgos constituyen el fiel reflejo de una prolongada fase de tránsito entre "lo orientalizante" y "lo prerromano", cuya identificación cultural en función de la propia evolución de este territorio parece estar más acorde con la expresión "Orientalizante o Tartésico Tardío" que con la de "Ibérico Inicial" habitualmente utilizada.

Pero a pesar de todo y al margen de cualquier controversia terminológica, este período de cierta recuperación - dentro de una fase global de declive y reconducción de "lo orientalizante" - debió ser tan efímero en el Bajo Guadalquivir como en el Valle Medio del Guadiana y su final queda especialmente representado en nuestra región en la misma destrucción e incendio de Cancho Roano en torno al 400 a. C. Sin duda, esta circunstancia, que conllevó el abandono absoluto del edificio con todo lo que representa, sí que parece reflejar una etapa mucho más crítica y definitiva que la que a fines del siglo VI a. C. (si se acepta nuestra hipótesis anteriormente planteada) no colapsó el desarrollo constructivo de este lugar, en cuyos orígenes algún día quizá encontremos las verdaderas claves del proceso orientalizador de este territorio y por tanto su posición concreta en el panorama protohistórico del Suroeste (López Pardo, 1990; González Wagner, 1993, 109; Rodríguez Díaz, 1994). Una cronología muy próxima a ésta comenzamos a barajar para la destrucción del complejo de La Mata (Campanario, Badajoz), cuya excavación codirigimos con P. Ortiz Romero. En este mismo contexto, estimamos que debe valorarse la ruina y abandono del asentamiento de la Atalayuela de Alcaracejos, en el norte cordobés. En este lugar, hace pocos años, un hallazgo accidental proporcionó un importante conjunto cerámico que fue dado a conocer sucesivamente por López Palomo (1987) y Murillo Redondo (1993). Concretamente, se trata de varios molinos barquiformes, un alisador con motivos oculados, un ánfora de tradición feno-púnica y diversos recipientes grises, pintados y comunes (platos de borde reforzado al interior, vasos de perfil en S, urnas, un embudo, cuencos, vasijas de cesta, etc.). A todo ello se suma la presencia de algunas cerámicas modeladas (cazuelas carenadas), una maza de minero, una torta de fundición de plomo y una posible tobera. Sin ser ajenos a la peculiaridad del yacimiento y su posible relación con la riqueza minera del entorno, ambos autores han valorado de forma un tanto desigual el significado cultural de estos materiales y la propia entidad del asentamiento. En nuestra opinión, dicho conjunto, que hemos podido recatalogar recientemente gracias a la amabilidad de D. Patricio Moreno, se caracteriza 
sobre todo por su homogeneidad y globalmente sus paralelos más próximos y precisos se encuentran en el edificio de Zalamea de la Serena. Asímismo, el contexto del citado muestreo (en el que hemos de reconocer no se encuentran cerámicas áticas) parece ofrecer también claras semejanzas con Cancho Roano, ya que — según su descubridor- aparecieron depositados en ẹl interior de una estancia construida con adobes y arruinada por un gran incendio. El aspecto que muestra actualmente el yacimiento es el de un gran túmulo de tierra, situado sobre una de las suaves ondulaciones que definen el paisaje de Los Pedroches (Rodríguez Díaz, 1995-a: fig. 3).

Lamentablemente, la estratigrafía del poblado de Medellín, como exponente mejor conocido de un tipo de asentamiento bien diferenciado del grupo anterior en cuanto a su localización en alto y a su clara filiación indígena, no es muy clara durante esta fase (Rodríguez Díaz, 1994). No obstante, a partir de los datos obtenidos del Corte 2 de 1991 , esta etapa en Medellín queda definida como una "fase postorientalizante", Medellín IIIC, con un carácter transicional entre el Orientalizante y la "Cultura de los Oppida en Extremadura". Con un significado claramente distinto al que hace años se dio al término "Postorientalizante", su cronología ha quedado fijada entre el 500 y el 450 a. C. (Almagro y Martín, 1994). Pero para el problema que centra nuestro trabajo resulta particularmente prometedor el hecho de que los estratos cenicientos asociados a esta fase Medellín III$\mathrm{C}$ (niveles 6 y 7) susciten a sus excavadores la duda sobre la existencia de un incendio parcial o generalizado en este poblado. Sobre su cronología, pensamos que la presencia de un "pequeño fragmento de cerámica ática aparecido en la parte inferior del estrato 4" (y por consiguiente prácticamente en contacto con este posible nivel de incendio) permitiría prolongar sin mayores problemas el final de Medellín III-C hasta finales del siglo $\mathrm{v}$ a. C. De admitirse dicha matización, en nuestra opinión, podrían comprenderse mejor los "productos áticos de fines del V" procedentes del propio Cerro del Castillo y de la necrópolis, la correlación estratigráfica entre esta fase y Cancho Roano o el origen de la "Cultura de los Oppida" (Medellín IV-A) a partir del 400 a. C.; una fecha, por otra parte, mucho más acorde con los resultados obtenidos hasta ahora en los sondeos estratigráficos realizados en la mayoría de los poblados prerromanos del Guadiana Medio (Rodríguez Díaz, 1987 y 1989).

Una observación paralela a ésta, cabría contemplar en la también reciente secuencia publicada del sector "Puerta de Carros" de la Alcazaba de Badajoz (Berrocal Rangel, 1994), un poblado de vado de características similares a Medellín. En síntesis y al margen de una ocupación prehistórica inicial (Período I), la protohistoria de este enclave se articula en dos fases o períodos culturales. El más antiguo, o Período II, se inscribe durante el Bronce Final-Período Orientalizante; y el más reciente, reconocido como Período III, ilustra por su parte la Segunda Edad del Hierro y el contacto romano. De los períodos protohistóricos, el publicado con más detalle es el último, cuya cronología se sitúa entre finales del siglo vi a. C. y mediados del siglo I a. C. Según Berrocal, el denominado Período III se inaugura, sin solución de continuidad respecto al anterior, con un nivel de ocupación (IIIA) fechado durante los siglos VI-IV a. C. Son características de este nivel las ánforas de tradición feno-púnica y las cerámicas grises, con paralelos claros en el 
Cerro Macareno, Medellín y Cancho Roano. Sin embargo, las bases cronológicas las proporcionan diversas piezas áticas de barniz negro y de figuras rojas. Mención aparte merecen las producciones a mano, ocasionalmente decoradas con motivos aplicados e impresiones digitales. A esta fase, se superpone el "Nivel de ocupación IIIB", datado entre los siglos IV y III a. C. Su rasgo más definidor es "la introducción masiva de las técnicas decorativas estampilladas en la cerámica común a torno y a mano". Aparte de los estampillados similares a los de Cogotas II o la Meseta Sur, destacan las grandes matrices geométricas de sabor portugués o las representaciones figurativas propias de Capote. Cerámicas pintadas y grises completan el repertorio cerámico de este nivel. A pesar de la valoración continuista que Berrocal hace de estas fases, en nuestra opinión resultan evidentes los signos de discontinuidad arqueológica y cultural existentes entre ambas. Así, mientras el nivel IIIA en efecto ofrece muestras inequívocas de raigambre orientalizante próximas al horizonte de Cancho Roano, el IIIB, asociado a una fase constructiva perfectamente diferenciada de la anterior por un pavimento, representa la refracción cultural que introduce la "celtización" de este territorio a partir del 400 a. C.

Finalmente, no podemos dejar de referir que situaciones paralelas de declive general o abandono definitivo de hábitats comienzan también a valorarse en el centro y sur de Portugal o en algunos ámbitos de la Meseta muy próximos a Extremadura. Así, por un lado, referir los niveles de destrucción e incendio documentados durante el siglo v a. C. en núcleos portugueses tan significativos como Alcácer do Sal, Fernao Vaz, Neves o Castro Marin (Ferreira y Varela, 1992, 167; Tavares y otros, 1980-81; Beirao, 1991; Pereira y Correa, 1985, etc.); por otra parte, destacar el fin traumático que, al parecer, conoce también el denominado "Ibérico Pleno" de Sisapo a la altura del estrato 8 (Fernández Ochoa y otros, 1994, 40).

En función de todo ello, quizá fuera oportuno contrastar también en el propio núcleo tartésico este momento de fines del siglo $\mathrm{v}$ a. C., que tan trascendental resultó para la periferia extremeña, por cuanto pueda contribuir a la explicación del abandono temporal o absoluto de poblados tan emblemáticos como Setefilla (Aubet y otros, 1983), el Cerro de la Cabeza (Domínguez y otros, 1988), y los núcleos minero-metalúrgicos de Río Tinto (Blanco y otros, 1970; Pellicer Catalán, 1983) o Tejada la Vieja (Blanco y Rothenberg, 1981; Fernández Jurado, 1987-b). Sin ánimos de entrar en un análisis pormenorizado de un asunto que en nuestra opinión merecería un trabajo con mayores ramificaciones, al menos consideramos que su referencia exige una mínima argumentación. En este sentido, especialmente sugerentes nos resultan las interrogantes que los propios excavadores de dichos asentamientos se plantean sobre las circunstancias que rodearon el fin de una ocupación prolongada tras el período expansivo que representa el siglo v. De este modo, Aubet, Serna, Escacena y Ruiz (1983, 34), al referirse a la fase final de Setefilla, constatan que los estratos III y IV (Fase V) son de naturaleza arcillosa y están separados entre sí "por una capa de cenizas y adobes quemados situados en la base de los muros del nivel III". Asímismo, precisan que "la inmensa mayoría de los hallazgos arqueológicos del Estrato IV, uno de los más ricos en este sentido del Corte 3, se concentran cerca del suelo del nivel (...) junto con restos orgánicos, carbones y adobes quema- 
dos". Finalmente, concluyen admitiendo que las causas del abandono definitivo de este lugar, entre los siglos v y IV a. C., "deben imputarse probablemente a factores económicos que, de momento, no estamos en condiciones de explicar. Sin embargo, sorprende el hecho que el poblado quedara deshabitado después de un momento floreciente y en pleno desarrollo cultural durante el siglo $\mathrm{v}$ a. $\mathrm{C}$., lo que viene a confirmar la idea de que las razones de su abandono deberán buscarse en factores económicos o ecológicos ajenos por completo a su desarrollo interno". Por otro lado, Domínguez, Cabrera y Fernández $(1988,124)$, al describir la estratigrafía del Cerro de la Cabeza en los niveles más recientes de su Corte B-I, concretan que el estrato II está "formado por tierra mezclada con tapial, más oscuro que el estrato anterior, con abundantes restos de carbón y cenizas". Por encima, el Estrato I se compone de "tierra compacta marrón oscura, con restos de tapial y adobe en abundancia" y a él se asocian numerosos restos de ánforas y "el hallazgo de un fragmento de kylix ático de fines del siglo $\mathrm{V}$ a. C.-comienzos siglo IV a. C.". Más adelante, al tratar de explicar las razones de un posible cambio de asentamiento a la Colina de San Antonio, dichos autores admiten que "hay que buscarlas dentro de un contexto general que afecta a todo el Bajo Guadalquivir y que comienza a producirse con la crisis económica planteada durante el siglo VI a. C. como consecuencia de la ruptura del mercado con las factorías fenicias. Unos poblados se abandonan (caso del Carambolo) y otros se modifican a raíz de la nueva distribución del espacio que toma cuerpo sobre todo a finales del siglo v a. C." (Domínguez y otros, 1988, 186). Asímismo, Blanco, Luzón y Ruiz $(1970,10-11)$ constatan abundantes restos de cenizas y carbones sobre el pavimento de las casas del Cerro Salomón, cuyo final en gran medida viene marcado por la presencia de cerámicas áticas de la segunda mitad del siglo v y primera mitad del IV a. C. También la cerámica griega parece marcar la última fase de ocupación de Quebrantahuesos (Pellicer Catalán, 1983, 85). Finalmente, Fernández Jurado (1987-b, 183) admite no poder determinar cuáles pudieron ser las causas del abandono definitivo y pacífico de Tejada la Vieja, fechado por cerámicas áticas en el siglo IV a. C., si bien insinúa una posible relación con las consecuencias derivadas del tratado romano cartaginés del 348.

Pero, además, hemos de significar que en otros asentamientos no menos representativos de Andalucía Occidental, donde la ocupación humana se prolonga durante gran parte de la segunda mitad del Ier. milenio a. C., el 400 parece manifestarse de un modo bastante traumático. De este modo, en el Cerro Macareno, sus excavadores reconocen que la estratigrafía de este lugar no muestra "grandes incendios ni destrucciones violentas salvo en la construcción sexta", encuadrada dentro del Ibérico Inicial y datable justamente en el tránsito de los siglos V-IV a. C., que podría corresponderse con "algún episodio bélico del mundo cartaginés en Iberia" (Pellicer y otros, 1983, 107-108). Una fecha dentro del siglo $\mathrm{V}$ a. C. fue barajada en alguna ocasión para el estrato de cenizas de Carmona (Pellicer Catalán, 1976-78), si bien las últimas apreciaciones sobre este lugar insisten en remontar a finales del VI dicho nivel (Escacena Carrasco, 1993, 191). Chaves y De la Bandera $(1988,373)$ admiten que en Montemolín el nivel 22 del sondeo realizado en el sector "Vico", incluido igualmente en el "Período Ibérico Inicial", se corresponde con "los restos de un gran incendio", datable por un asa de kylix griego en fechas próximas 
al del Macareno. Por último, en idéntico contexto crono-cultural parece que deba incluirse la destrucción con incendio del nivel 17 del sondeo San Isidoro 85-6 (Sevilla capital) en función de determinadas ánforas iberopúnicas con paralelos directos en el Macareno a fines del siglo v a. C. (Campos y otros, 1988, 37; fig. 23, 401).

En resumen, este breve análisis de determinadas fases estratigráficas de algunos poblados tartésicos deja entrever que en el último tercio del siglo $\mathrm{V}$ a. C. se reproducen una serie de acontecimientos muy negativos para estos núcleos, que en su conjunto parecen definir una nueva etapa de recesión para buena parte del cuadrante suroccidental. Aunque todavía estamos lejos de poder determinar las razones internas y externas de esta "crisis del cuatrocientos", resulta evidente que éstas no obedecen a coyunturas locales o comarcales, sino - como ya ocurriera a finales del siglo VI a. C. - a factores socioeconómicos y culturales más amplios que alteraron sustancialmente la proyección lógica que debió seguir al período de recuperación y expansión representado en el siglo V. Aunque bien es cierto que los efectos de esta nueva recesión se constatan en no pocos poblados bajoandaluces, las mayores y más trascendentes consecuencias se registran en los yacimientos septentrionales y occidentales de la antigua periferia tartésica. En definitiva, todo ello parece indicar que no será hasta este momento cuando se consoliden en el Suroeste, en general, y en la "periferia extremeña", en particular, las alternativas socioeconómicas que sustituyan definitivamente las bases del "modelo orientalizante" que dinamizó esta zona durante casi toda la primera mitad del Ier. milenio a. C.

Ni que decir tiene que, en este contexto global, la reconstrucción y destrucción de Cancho Roano (y quizá también de la Atalayuela de Alcaracejos o La Mata de Campanario) parece cobrar un mayor sentido, por cuanto, por una parte, dicho asentamiento participa de una etapa de recuperación y expansión socioeconómica como es el siglo $\mathrm{v}$ a. C.; y, por otra, su final se aleja de cuestiones estrictamente locales o rituales en favor de su mayor integración en una situación más general y crítica que parece afectar también a buena parte del Suroeste. Por último y desde una perspectiva cultural, será igualmente a partir de esta nueva etapa cuando realmente el sustrato orientalizante se desdibuje y comience a fundamentarse la disgregación etnocultural de este amplio espacio, que - según los textos grecolatinos- estaba compartido por turdetanos, túrdulos y célticos a la llegada de los romanos (García y Bellido, 1945 y 1947; Schulten y Maluquer, 1987).

En este sentido y centrándonos en el ámbito extremeño, se viene admitiendo por estas fechas próximas al 400 a.C. la génesis de la Beturia (Plinio, III, 13-14), dentro del progresivo y diacrónico proceso de "celtización" que por entonces afectó a la mayor parte del occidente peninsular. Un proceso que, por otra parte, posee su área nuclear en la Celtiberia y que, al parecer, mantiene notables imbricaciones con otros círculos culturales peninsulares e incluso extrapeninsulares (Almagro Gorbea, 1990, 1992 y 1994; Lorrio Alvarado, 1994). En la zona objeto de estudio y al margen de planteamientos invasionistas, parece lógico pensar que la citada crisis del 400 debió favorecer los importantes reajustes demográficos que, tanto en sentido Norte-Sur como Este-Oeste, generaron a su vez complejos y profundos procesos interétnicos y culturales de los que, 
desde ópticas diferentes, se han ocupado numerosos investigadores (Palomar Lapesa, 1957; Albertos Firmat, 1966 y 1975; Unterman, 1965 y 1985; Almagro y Lorrio, 1987, etc.)

Arqueológicamente, este nuevo panorama en la Cuenca Media del Guadiana parece concrertarse en el declive y/o abandono de no pocos núcleos orientalizantes (sobre todo aquéllos alejados de los vados del Guadiana) y el surgimiento de pequeños poblados de cuya ubicación se entreven nuevas estrategias económicas y territoriales respecto a la fase anterior y de sus restos materiales una reconducción de las tradiciones orientalizantes hacia estilos de marcado carácter meseteño. En este contexto, parece situarse el origen de núcleos como El Castañuelo (Del Amo, 1978; Pérez Macías, 1990) o los niveles inferiores de Capote (Berrocal Rangel, 1992), enclaves insistentemente reconocidos como "célticos" durante los últimos años. Sin embargo, no por ello desaparecerán de un modo definitivo los vínculos seculares entre el Guadiana y el Guadalquivir, de tal forma que buena parte del actual territorio extremeño continuará siendo periferia turdetana del mismo modo que siglos atrás lo fuera de Tartessos. Pero a pesar de todo, éste continúa siendo un período oscuro de la protohistoria del Guadiana Medio, en el que se mantiene como uno de los principales temas de estudio determinar la etnogénesis y las circunstancias que rodearon la llegada de los referidos "célticos" a este territorio. De cualquier forma, en el estado actual de la investigación resulta obligado pasar al análisis del período inmediatamente posterior para entender y calibrar la verdadera trascendencia de esta fase de alternativa al fin de la supremacía tartésica.

\section{LA REORGANIZACIÓN DEL TERRITORIO Y LA CONFIGURACIÓN DE LA "BETURIA PRERROMANA"}

Aparte de la adscripción inicial de los primeros castros conocidos al indefinido mundo de las "citanias" que hicieran autores como el Marqués de Monsalud o Roso de Luna, la valoración global de esta etapa ha pasado por expresiones como "Postorientalizante", "Cultura de los Castros" (Almagro Gorbea, 1977), "Segunda Edad del Hierro", "Poblamiento prerromano" (Rodríguez Díaz, 1987 y 1989), "Pueblos célticos o betúricos" (Berrocal Rangel, 1992) y más recientemente "Cultura de los Oppida de Extremadura" (Almagro y Martín, 1994) y "Beturia prerromana" (Rodríguez Díaz, 1993 y 1995-b). Aunque con criterios y concepciones metodológicas diferentes, son todas ellas expresiones que, en mayor o menor medida, tratan de subrayar la personalidad del espacio cultural surgido entre el Guadiana y Sierra Morena durante los siglos IV y III a. C. En nuestro caso concreto, tratamos, además, de identificar el profundo proceso de reorganización territorial que, tras el vacío e incertidumbre generada por el fin de la hegemonía tartésica, introduce la "continentalización" o "celtización" del pasado orientalizante; un proceso que, en nuestra opinión, individualiza y diferencia la actual región extremeña de las grandes áreas de la Cultura Ibérica (Rodríguez Díaz, 1990; Rodríguez y Enríquez, 1992).

En este sentido, podemos concretar que uno de los aspectos más singulares y definidores de esta nueva etapa, sin duda alguna, lo constituye el desarrollo de un impor- 
tante número de asentamientos que, en líneas generales, responden a los factores de localización de un "castro": lugares con buenas condiciones defensivas, entornos preferentemente ganaderos y/o minero-metalúrgicos, proximidad a un río de caudal permanente y suficiente dominio visual de los más inmediatos pasos o puertos. Dichos asentamientos se sitúan en lugares no excesivamente elevados, poco diferenciados en el paisaje y, por lo general, no habitados en la fase Bronce Final-Período Orientalizante. En este patrón poblacional, las excepciones las representan los principales vados del Guadiana que de forma obligada han concentrado el tráfico humano a lo largo de los siglos (Rodríguez Díaz, 1995-c). En definitiva y como queda dicho, todo parece apuntar hacia una importante reorganización del territorio respecto al período anterior que, como es lógico, implica a su vez el desarrollo de una nueva estrategia de control y explotación de sus recursos potenciales. Dicha estrategia, que provocó una ocupación selectiva del espacio diferente a la desarrollada por los orientalizados pobladores de siglos antes, constituye a nuestro juicio la esencia de lo que los autores grecolatinos acabarían identificando como "Baeturia": un ámbito geográfico de suficiente entidad, cuya personalidad debió radicar en su carácter periférico y/o fronterizo respecto al Bajo Guadalquivir y que culturalmente se configura como el punto de tránsito y confluencia entre célticos y turdetanos. En cierto modo, creemos que así la entendió ya García Iglesias en su reconocido trabajo de 1971, al considerarla como "el conjunto de tierras desconocidas situadas más allá del Betis (...), misteriosas en un principio, poco pobladas y, tras la llegada de los invasores indoeuropeos, partidas entre dos pueblos de tan diverso signo como los que cita Plinio y, más veladamente Ptolomeo" (García Iglesias, 1971, 105).

Pero, como ya hemos apuntando en varios trabajos recientes, dentro de este panorama general, la investigación de los últimos años comienza a dejar entrever, cada vez en mayor grado, la existencia de notables diferencias interregionales que parecen estar en relación con una desigual intensidad del referido proceso de "celtización" y una no menos desigual persistencia de las tradiciones orientalizantes en determinadas comarcas de esta zona. Tales contrastes territoriales y culturales encuentran su mejor expresión en la identificación diferenciada que los autores grecolatinos hicieron de este espacio: la "Beturia de los célticos" y la "Beturia de los túrdulos".

El estudio de la época prerromana en el sector céltico de la Beturia se fundamenta en los trabajos realizados durante los últimos años en los poblados de la Sierra de la Martela de Segura de León (Enríquez y Rodríguez, 1988), Los Castillejos de Fuente de Cantos (Fernández y otros, 1988), la Ermita de Belén de Zafra (Rodríguez Díaz, 1991-a), la Alcazaba de Badajoz (Valdés Fernández, 1979; Berrocal Rangel, 1994), Capote de Higuera la Real (Berrocal Rangel, 1988 y 1989-b) y ya en territorio portugués Segovia (Júdice Gamito, 1981). Son todos ellos asentamientos por lo general poco extensos y de marcado carácter castreño (entre 1 y $3 \mathrm{Ha}$.), que a veces se confunden en un paisaje adehesado y montuoso regado por los ríos Ardila, Alcarrache o el propio Guadiana. Aunque Berrocal Rangel (1992) ha defendido recientemente la existencia desde este momento de una red jerarquizada de asentamientos en torno a Nertóbriga, consideramos dicha propuesta cuanto menos prematura en virtud del desconomiento que aún se tiene de las 
estratigrafías de estos enclaves. Precisamente, las evidencias arqueológicas que comienzan a conocerse de Nertóbriga y de otros conocidos "oppida de la Beturia" invitan a contemplar otras posibilidades sobre el verdadero papel de estos "lugares centrales" (Rodríguez Díaz, 1995 a-c). La organización interna de estos asentamientos, a juzgar por la orientación uniforme de las construcciones domésticas conocidas hasta el momento, parece obedecer a un plan organizado. Sin duda el caso mejor conocido hasta ahora es el del Castrejón de Capote, donde a partir de una "calle central" se delimitan dos manzanas de viviendas configuradas por estancias rectangulares de dimensiones variables. $\mathrm{Ni}$ que decir tiene que todos estos aspectos poseen evidentes semejanzas con los poblados celtibéricos (Berrocal Rangel, 1989-b; Blasco Bosqued, 1987 y 1989; Almagro Gorbea, 1990) y constituyen, además, elementos de gran valor para profundizar en el estudio de las relaciones culturales que definieron este territorio durante la II Edad del Hierro.

Los pilares económicos de estos lugares parecen residir en la explotación sistemática de los variados recursos de la dehesa y los abundantes filones férricos de esta zona. Respecto al primer punto, los pastos y una ganadería de tipo mixto dominada por los ovicaprinos parecen ocupar un lugar preferente respecto a la agricultura. Por su parte, la proximidad de estos asentamientos a los referidos recursos férricos del subsuelo y los testimonios metalúrgicos recuperados en el transcurso de las excavaciones (hornos, herramientas, escorias) sugieren un alto grado de especialización de estas comunidades en la explotación del hierro (Rodríguez Díaz, 1989 y 1990; Canto, 1991; Berrocal Rangel, 1992).

Dicha reconducción económica también tiene una clara correspondencia en el plano tecnológico y cultural. Aunque necesariamente breve, una valoración global de este aspecto revela una serie de particularismos entre los que destaca el elevado porcentaje de cerámicas modeladas, lisas o decoradas con motivos inciso-impresos, a peine, aplicados y estampillados muy simples. Son materiales que, derivados de las tradiciones alfareras de la Meseta y el Valle del Ebro, carecen de antecedentes inmediatos en nuestra región y, en general en el Suroeste, pero que durante este momento se difunden con especial intensidad por todo el territorio alentejano-extremeño. A pesar de ello, tales materiales comparten espacio y gusto con determinados objetos propios del Mundo Ibérico y las tecnologías de tradición orientalizante, como lo demuestran la presencia en estos poblados de falcatas, cerámicas grises torneadas o las placas áureas de Segura de León (Enríquez y Rodríguez, 1985; Berrocal Rangel, 1989-a). En su conjunto y a nuestro juicio, todos estos aspectos son signos evidentes de las fuertes imbricaciones culturales surgidas en este sector del Guadiana Medio a partir del ocaso orientalizante y tras el nuevo equilibrio socioeconómico y cultural representado en estos nuevos asentamientos; un equilibrio que, aunque dirigido por las nuevas élites de signo meseteño, también ha de contemplar el papel jugado por los elementos autóctonos del Guadiana Medio atraídos a estos focos por el carácter emergente de la zona.

Ante la falta de una información sistematizada sobre los comportamientos funerarios y religiosos de estas comunidades, la refración cultural en el plano ideológico de este período la capitaliza por el momento el denominado "Altar A de Capote" (Berrocal 
Rangel, 1994-a). Como es sabido, en dicho lugar quedaron fosilizados los restos de una posible celebración ritual, quizá vinculada al ciclo solar y de claras connotaciones atlánticas, que debió constituir, sin duda, el mayor factor de cohesión social de esta comunidad y por ende el pilar más sólido de su identidad étnico-cultural. A todo ello, qué duda cabe, habría que anadir la tan reiterada sustitución de la "escritura tartésica" por otra que al latinizarse generó ejemplos antroponímicos y toponímicos tan conocidos y divulgados como "Tancinus", "Ablonios" o las radicales y terminaciones en "Seg-" y "-briga" de algunas poblaciones.

En resumen, la articulación de la información que para época prerromana sobre este sector de la Beturia poseemos hasta ahora nos permite discernir un panorama socioeconómico y cultural bastante homogéneo y personalizado, que, en nuestra particular opinión, constituyó (quizá sin pretenderlo) la más sólida alternativa al agotamiento del "modelo tartésico". Entre los aspectos más sobresalientes de este proceso destacamos la reorganización global del territorio a partir del "castro" como asentamiento tipo; el desarrollo de un nuevo modelo económico fundamentado en la explotación sistemática del hierro y de los pastos; y, por último, la interacción y más que probable fusión de determinadas poblaciones meseteñas con grupos autóctonos herederos de las tradiciones orientalizantes. Aunque aún desconocemos el carácter y las circunstancias que rodearon la llegada al Guadiana Medio de los referidos elementos meseteños, reconocidos por las fuentes como "célticos", parece lógico relacionar dicha coyuntura con la incertidumbre generada por la etapa crítica del 400 a. C. Aun así, hemos de admitir que estamos lejos de desentrañar la verdadera realidad étnica que esconde la genérica expresión de "célticos", tan insistentemente utilizada por los autores grecolatinos.

Por otro lado, el conocimiento del sector extremeño incluido en la "Beturia de los túrdulos" durante época prerromana resulta mucho más restringido. En este sentido, podemos concretar que la información más detallada sobre este período procede de Medellín (Almagro y Martín, 1994) y la Tabla de las Cañas (Domínguez y García, 1991), si bien dichos asentamientos forman parte de una amplia serie de lugares prospectados entre los que sobresalen Entrerríos (Almagro y Lorrio, 1986), Magacela, El Casarón de La Coronada, Los Vadillos de Esparragosa de Lares, Las Poyatas de Zarza Capilla, El Pez, Las Dehesillas (Rodríguez e Iñesta, 1984), el Castillo de Alange (Enríquez Navascués, 1988) y quizá Cogolludo (Aguilar y Guichard, 1993). En líneas generales, se trata de poblados cuya extensión oscila entre 1 y $7 \mathrm{Ha}$, aunque para el caso de Medellín se ha calculado una superficie habitada próxima a las $20 \mathrm{Ha}$. Dichos asentamientos ocupan altitudes igualmente variables en un paisaje vertebrado en amplios corredores naturales de dirección NW-SE, modelados por los ríos Zújar, Guadámez y Matachel. Tomando una vez más el caso de Medellín como modelo, Almagro Gorbea defiende la existencia de un territorio jerarquizado en torno a grandes "oppida", resultantes del "final de un largo proceso de evolución de las estructuras socioeconómicas y políticas orientalizantes". Aunque la existencia de núcleos menores como el de la Tabla de las Cañas pudiera dar argumentos a dicha red de asentamientos, valoraciones tan deudoras de la dinámica explicativa de otras regiones mejor conocidas exigen en 
nuestra opinión un mayor nivel de contrastación en una zona en la que precisamente la mayor concentración de poblados se registra en los valles limítrofes del Zújar y del Matachel. Son lugares fácilmente defendibles, de cuyas defensas se reconocen en superficie dos o tres recintos amurallados. Salvo la constación de sus trazados regulares y organizados dentro del recinto, las viviendas de estos asentamientos prácticamente nos son desconocidas. En ocasiones, también se advierte la presencia de aljibes interiores excavados en la roca. Como rasgo destacable, señalar la existencia de pequeños peñones fortificados y posibles caseríos agrícolas localizados en las proximidades de los enclaves de mayor entidad. No obstante, hemos de admitir que dichos núcleos parecen corresponder mayormente a época republicana, si bien ninguno de ellos ha sido sondeado

La estructura socioeconómica de este sector túrdulo de la Beturia debió girar en torno a la explotación combinada de los extensos pastizales interiores, la caza y las feraces vegas aluviales del Zújar y Guadiana. Molinos y molederas de diverso tipo son las únicas evidencias de una agricultura que debió ser eminentemente cerealística. Por su parte, la ganadería continúa fundamentándose en la gestión diferencial de especies como la oveja, la cabra y el vacuno, según se desprenden de los muestreos óseos parcialmente publicados. Sin duda, el mejor complemento de todo ello debió ser una vez más la explotación de las posibilidades minero-metalúrgicas del subsuelo de esta zona. Éstas se concretan en frecuentes mineralizaciones de hierro y en un enorme potencial de galenas argentíferas, cuyo beneficio de plomo y plata están especialmente documentados durante época republicana (Domergue, 1970, 1985 y 1987).

Como es fácil deducir, un conocimiento tan global e impreciso de la economía de estos poblados se traduce en un no menos facetado análisis de sus aspectos tecnoculturales. No obstante y en virtud de los materiales asociados a la fase I de la Tabla de las Cañas y a la reconocida como Medellín IV, se detectan notables contrastes respecto a los poblados célticos. Sin faltar la cerámica modelada, predominan las cerámicas de cocción oxidante morfológica y decorativamente afines a los criterios y gustos propios del Guadalquivir, la Meseta Sur y el Mundo Ibérico. En este contexto, cobran mayor sentido hallazgos tan conocidos de esta zona como el Sileno de Capilla (Olmos Romera, 1977), el peine tipo Serreta de Medellín (Almagro Gorbea, 1977), las joyas de plata de Orellana la Vieja (Fernández Avilés, 1958) o los exvotos de bronce procedentes de Mérida-Medellín (Almagro y Del Amo, 1985). Por su parte, las tecnologías de tradición orientalizante siguen encontrando en la cerámica gris y en la orfebrería sus mejores exponentes. Por reciente, quizá resulte oportuno poner como ejemplo de esta última serie de objetos una arracada, datada en el siglo IV a. C., procedente de un contexto funerario asociado a Cogolludo (Aguilar y Guichard, 1993). En suma, dichos elementos parecen situarnos en términos muy globales ante criterios y gustos tecnológicos que, sin ser ajenos a los influjos meseteños, están más próximos a los círculos culturales del sur peninsular en función quizá del todavía latente pasado orientalizante.

En este sentido, sería muy deseable contrastar dichos aspectos con otros con un mayor significado étnico como son las costumbres funerarias y religiosas. Pero lamenta- 
blemente, al tratar estas cuestiones a menudo nos vemos obligados a recurrir a manifestaciones y hallazgos de cronología romana (Rodríguez Díaz, 1991; López Melero, 1986; Blázquez Martínez, 1986). A pesar de las limitaciones que ello comporta, insistimos en subrayar las diferencias entre "lo túrdulo" y "lo turdetano" a partir de la interacción sobre un asentado sustrato orientalizante de elementos cogoteños, turdetanos e incluso neopúnicos (García y Bellido, 1991); interacción surgida justamente en los límites territoriales comunes entre La Meseta y el Guadalquivir. Quizá este mestizaje cultural constituyera también para algunos autores clásicos (Plinio, III, 14-15; Polibio, XXXIV, 11) el argumento principal de diferenciación entre "turdetanos" y "túrdulos", reservando esta última denominación (que en sí misma no es más que una derivación de turdetanos) para designar a los "turdetanos del interior", menos romanizados y más influidos por las poblaciones célticas (Estrabón, III, 1, 6 y III, 2, 15).

En resumen y con los datos que poseemos en la actualidad, la "Beturia de los túrdulos" se nos muestra como un espacio cuyo poblamiento prerromano se articula en torno a lugares fortificados de extensión y ubicación variables, con una especial concentración en sus áreas limítrofes y, por tanto, una menor densidad en las centrales. Sin estar estos planteamientos suficientemente contrastados, no dejan de ser por ello aspectos sugerentes para la investigación futura de esta región; una investigación en la que, dicho sea de paso, no debe en ningún caso despreciarse el análisis interrelacionado del fin del sistema socioeconómico representado en la destrucción de Cancho Roano y la formación de la "Beturia Céltica" como foco sociocultural emergente. Fruto de ello pudo ser no sólo la ya referida coexistencia en el suroeste de Badajoz de tradiciones tecnológicas diversas, sino también la difusión hacia la zona objeto de estudio de unas fórmulas de recuperación económica basadas en la potenciación de la explotación de los pastos y la metalurgia del hierro así como de otros aspectos materiales o ideológicos como son ciertas modas cerámicas o determinadas creencias religiosas y rasgos lingüísticos propios del mundo meseteño. Pero, en nuestra opinión y con la prudencia obligada que impone el estado actual de la investigación o la valoración conjunta de esta zona con el norte cordobés y el foco minero de Almadén, la verdadera entidad de este espacio en el contexto global de la Beturia debió radicar en el control y canalización de los contactos con el Guadalquivir y la Meseta Sur, como parece derivarse de los aspectos tecno-culturales tratados con anterioridad.

\section{EL IMPACTO ROMANO Y LA CONFIGURACIÓN DE LA BETURIA CLÁSICA}

Como es sobradamente conocido, las primeras noticias que se tienen sobre la presencia inicial romana en esta zona nos sitúan a comienzos del siglo II a. C., si bien su plena anexión no se produciría hasta casi dos siglos más tarde. Aunque dicha etapa mantiene aún considerables lagunas arqueológicas, nuestra intención aquí es simplemente insistir en algunos aspectos sobre el poblamiento que, en la medida de nuestras posibilidades, contribuyan a una lectura más fluida de los profundos cambios que caracterizan 
este período. Baste señalar como ejemplo en este sentido la gran diversidad de enclaves documentada, durante los dos siglos que anteceden al cambio de Era, en todo el Guadiana Medio como consecuencia de la intensa política territorial y de relocalización de elementos indígenas previa a la fundación de "Augusta Emerita". En la actualidad, tal variedad poblacional se articula en tres grupos de ocupaciones hasta hace poco escasamente diferenciados: los propios castros indígenas que experimentaron el contacto inicial romano, los tan referidos "oppida" de la Beturia y la red de construcciones ciclópeas de La Serena (Rodríguez Díaz, 1995 b-c)

Sobre las consecuencias del contacto romano con los poblados indígenas, la mayor información procede del sector céltico de la Beturia cuya oposición a los romanos junto a vettones y lusitanos está suficientemente contrastada. En este contexto y al margen de aquellos lugares en los que intuimos un abandono definitivo, adquieren un mayor sentido los niveles de destrucción documentados en poblados como Los Castillejos de Fuente de Cantos, la Ermita de Belén o Capote, a partir de los cuales se hacen frecuentes las cerámicas campanienses, las ánforas Dressel I o la amonedación republicana. Aunque con menor detalle, episodios similares debieron producirse en la "Beturia de los túrdulos", según se desprende de la destrucción que marca el final de fase inicial de la Tabla de las Cañas (Domínguez y García, 1991). Pero tanto en una zona como en otra de la Beturia a dichas destrucciones, suceden rápidas reconstrucciones y nuevas ruinas que prolongan la vida de estos poblados, unas veces, hasta un momento impreciso del si-glo I a. C. y, otras, hasta época altoimperial (Rodríguez Díaz, 1989 y 1990). Pero a pesar de este ambiente de conflictividad continuada, todo parece indicar que, tras los enfrentamientos del primer momento y tal como sucede en otras regiones peninsulares, los romanos mantuvieron e incluso potenciaron la estructura socioeconómica indígena (López Melero y otros 1984). Así, en el sector céltico de la Beturia, dicha estructuración siguió estando basada en la ganadería ovicaprina y bovina y muy especialmente en la metalurgia del hierro (Canto, 1991 y 1995). Como las recientes investigaciones de esta autora están poniendo de relieve, este área durante gran parte de esta nueva etapa continuó manteniendo una categoría económica y sociocultural muy destacada dentro de la estrategia de anexión y explotación territorial desplegada por los romanos. De hecho, considera incluso la definición en esta zona de un auténtico distrito minero o "ferrum Baeturicum", similar al "ferrum Noricum" de época imperial (Canto, 1991, 275). Por otro lado, en la "Beturia Túrdula" muy pronto empezarían a administrarse soluciones parecidas en torno la explotación sistemática del plomo argentífero (Domergue, 1970 y 1987).

Pero de forma paralela a dicho proceso de sometimiento y explotación del territorio a partir de la reconstrucción controlada de los castros indígenas, comenzaría a tejerse una trama de asentamientos de gran tamano cuyas estratigrafias se inscriben entre la etapa tardo-republicana y los siglos I-II d. C. No es casualidad que la mayor parte de estos lugares "ex novo" se correspondan con los "oppida" selectivamente recogidos en la literarura clásica. Entre los ejemplos que comienzan a conocerse con mayor profundidad destacan los de Nertóbriga, Miróbriga (Pastor y otros, 1992), y Hornachuelos 
(=Fornacis?) (Rodríguez Díaz, 1991), si bien a ellos habría que anadir la potenciación y promoción de estratégicos lugares ocupados durante toda la protohistoria como Medellín y Cogolludo-Lacimurga (Canto, 1989; Aguilar y Guichard, 1993). Todo ello, en nuestra opinión, daría fundamento arqueológico al planteamiento por el que consideramos que el origen y la entidad político-administrativa alcanzada poco después por estas "nuevas fundaciones" dentro de una estrategia de relocalización y concentración de poblaciones indígenas en determinadas áreas de interés militar y económico para los romanos (Estrabón, II, 1, 6). De confirmarse tal hipótesis mediante un conocimiento estratigráfico más amplio de estos enclaves, sería fácil considerarlos como verdaderas "células de romanización" y, por consiguiente, el germen de las transformaciones definitivas de la estructura socioeconómica e ideológica de las comunidades prerromanas del Guadiana Medio. Bien sabido es que la conquista y la implantación progresiva de la administración romana promovió precisamente la concentración de las poblaciones indígenas en unidades de poblamiento mayores en las que acabarían diluyéndose sus señas de identidad (Rodríguez Díaz, 1995). Aunque bajo circunstancias sociopolíticas diversas, en este contexto parece adquirir una mayor sentido las políticas de colonización e integración que de un modo progresivo desarrollarían César, Augusto y los emperadores flavios sobre estos núcleos (Canto, 1989 y 1995; Stylow, 1991); unos "lugares centrales" cuya complejidad estructural responde casi mejor a la semántica del concepto "Cultura de los Oppida" aplicado por Almagro y Martín (1994) a la etapa precedente y que, en su globalidad, se corresponde plenamente con el paisaje de la Beturia clásica descrito por las fuentes.

Considerados en un primer momento de su investigación dentro de la organización territorial prerromana, actualmente los recintos ciclópeos de la Serena comienzan a valorarse en función del alto grado de especialización de sus esquemas constructivos. Con una actividad centrada entre los siglos I a. C. y I d. C., la finalidad de dichos recintos cada vez parece estar más directamente implicada con la explotación minera y el control militar romano de esta amplia ruta que es en sí misma La Serena, escenario privilegiado de los conflictos civiles (Ortiz Romero, 1995). Ambos aspectos, el control estratégico del camino natural hacia Córdoba y la explotación del plomo argentífero, se ponen por sí mismos en conexión directa con sucesos tan conocidos como la fundación de Medellín y la puesta en valor de otras zonas mineras inmediatas como son Azuaga, Almadén y el noroeste cordobés (Domergue, 1970 y 1987). En cierto modo, podríamos concluir diciendo que esta zona recuperó, merced a la presencia romana, el protagonismo perdido tras el 400 a. C. Pero lo hizo de la única forma posible: revitalizando su carácter de frontera permanente y justificando así el carácter de territorio militar que mantuvo hasta época muy avanzada. Sea como fuere, lo cierto es que en la Cuenca Media del Guadiana a finales del siglo I d. C., tras la fundación de "Augusta Emérita" y la reorganización políticoadministrativa de la Ulterior en dos provincias, la disolución definitiva de la Beturia era ya una realidad. 


\section{BIBLIOGRAFÍA}

AA. VV., 1987: La minería en Extremadura. Mérida.

AgUILAR, A., y GUICHARD, P., 1993: Villes romaines d'Estrémadure. Doña María, La Sevillana et leur environnement. Madrid.

Albertos Firmat, M. L., 1966: La onomástica personal primitiva de Hispania. Tarraconense y Bética. Salamanca.

- 1975: “Organizaciones suprafamiliares en la Hispania Antigua”. StA 37.

Almagro Gorbea, M., 1977: "El Bronce Final y el Período Orientalizante en Extremadura". BibPrHisp XIV. Madrid.

- 1983: "Colonizzazione e acculturazione nella Penisola Ibérica". Modes de contacts et processus de transformation dans les sociétées anciennes. Pise-Rome. 429-461.

- 1990: "Segunda Edad del Hierro. La celtización de la Península Ibérica". Historia de España, I. Ed. Planeta. Madrid. 554-562.

- 1992: "El origen de los celtas en la Península Ibérica: proto-celtas y celtas", Polis 4, 5-31.

- 1993: "Tarteso desde sus áreas de influencia: la sociedad palacial en la Península Ibérica". Los enigmas de Tarteso. Madrid. 139 ss.

- 1994: "Los Celtas en la Península Ibérica: origen y personalidad cultural". Los Celtas: Hispania y Europa. Madrid. 121 ss.

Almagro Gorbea, M., y Del Amo, M., 1985: "Bronces ibéricos en Extremadura". HomCánovas. Badajoz. 71-86.

Almagro Gorbea, M., y Domínguez de la CONCHA, A., 1988-89: "El palacio de Cancho Roano y sus paralelos arquitectónicos y funcionales». Zephyrus XLI-XLII. 339-382.

Almagro Gorbea, M.; Domínguez de la Concha, A., y López Ambite, F., 1990: "Cancho Roano, un palacio orientalizante en la Península Ibéricar. MM 31.252-308.

Almagro Gorbea, M., y Lorrio Alvarado, A., 1986: "El castro de Entrerríos (Badajoz). REstBadajoz XLII, 47 y ss.

- 1987: "La expansión céltica en la Península Ibérica: una aproximación cartográfica". Celtiberos I. Daroca, 1986. 105-122.

Almagro Gorbea, M., y Martín Bravo, A., 1994: "Medellín 1991. La ladera norte del Cerro del Castillo". Complutum Extra 4. 77 y ss.

Aubet Semmler, M. E., 1987: Tiro y la colonias fenicias de Occidente. Barcelona.

- 1990: "El impacto fenicio en Tartessos: las esferas de interacción". La Cultura Tartésica y Extremadura. Mérida. 31-44.

- 1995: "From Trading Post to Town in the Phoenician-Punic World". Proceedings of the British Academy, 86, 47-65.

Aubet, M. E.; Serna, M. R.; Escacena, J. L., y Ruiz, M. M., 1983: "La Mesa de Setefilla. Lora del Río (Sevilla). ExArqEsp 122. 
BEIRAO, C. M., 1991: Une civilisation protohistorique su sud du Portugal. 1er. Age du Fer. París.

Belén Deamos, M., y Escacena Carrasco, J. L., 1990: “Niebla (Huelva). Excavaciones junto a la Puerta de Sevilla (1978-1982). La Cata 8". HuelvaA XII.

- 1992: "Las comunidades prerromanas de Andalucía Occidental”. Paleoetnología de la Península Ibérica, Complutum 2-3. 65 ss.

Belén, M.; Fernández-Miranda, M., y Garrido, J. P., 1977: "Los orígenes de Huelva. Excavaciones en los Cabezos de San Pedro y La Esperanzar. HuelvaA III.

Berrocal RANGel, L., 1988: Excavacines en Capote (Beturia Céltica), I. Serie Nertobriguense, I. Fregenal de la Sierra.

- 1989-a: „Placas áureas de la Edad del Hierro en la Meseta Occidental. TrabPrHist 46. 279-291.

- 1989-b: "El asentamiento céltico del Castrejón de Capote (Higuera la Real, Badajoz)». CuPAUAM. 16, 245-295.

- 1990: "Materiales cerámicos a mano de una necrópolis nertobriguense (El Cantamento de la Pepina, Badajoz).. Celtíberos II. Zaragoza. 311-316.

- 1992: "Los pueblos célticos del Suroeste de la Península Ibérica", Complutum. Extra 2. Madrid.

- 1994: "El oppidum de Badajoz". Complutum Extra 4.143 y ss.

Blanco FreijeIro, A., 1983: "Ategua. NAHisp 15. 95-135.

Blanco Freijeiro, A., y Corzo SÁnCHEZ, R., 1981: “Der neue anthropoide sarkophag von Cádiz". MM 22. 236-243

Blanco Freijeiro, A., y RothenBerg, B., 1981: Exploración arqueometalúrgica de Huelva. Huelva.

Blanco, A.; Luzón, J. M., y RuIz, D., 1970: “Excavaciones arqueológicas en el Cerro Salomón (Río Tinto, Huelva)». AnHisp 4. Sevilla.

Blasco BosQued, C., 1987: "La España celtibérica: La Segunda Edad del Hierro en la Meseta". Historia General de España y América, I-2. Madrid. 297-327.

- 1989: "El fenómeno céltico". Los celtas en el Valle Medio del Ebro. Zaragoza. 15-38.

BLÁZQuez Martínez, J. M., 1983: Religiones Prerromanas (Primitivas Religiones Ibéricas). Madrid.

Cabrera Bonet, P., 1987: “Consideraciones en torno a la cerámica ática de fines del siglo V en Extremadura. Oretum, III. 215-222.

- 1988-89: "El comercio foceo en Huelva", Huelva A X-XI. 41-100.

- 1994: "Cádiz y el comercio de productos griegos en Andalucía Occidental. TrabPrbist 51-2. 89 ss.

Campos, J.; Vera, M., y Moreno, M. T., 1988: -Protohistoria de la ciudad de Sevilla. El corte estratigráfico San Isidoro 85-6.. MonArqAnd 1. Sevilla. 
Canto de Gregorio, A., 1989: "Colonia Iulia Augusta Emerita: Consideraciones en torno a su fundación y territorio". Gerión 7. 149-205.

- 1991: Noticias arqueológicas y epigráficas de la Beturia Céltica, CuPAUAM 18, 275-298.

- 1995: "La Beturia Céltica en época romana”. Célticos y Túrdulos: la Beturia. Mérida, 1994.

CARO, A.; ACOSTA, P., y ESCACENA, J. L., 1986: “Informe sobre la prospección arqueológica con sondeo estratigráfico en el solar de la calle Alcazaba (Lebrija, Sevilla)». AnArqAnd 1986-II. 168 ss.

CARRIAZO, J. M. (1973): Tartessos y el Carambolo. Madrid.

CARRIAZO, J. M., y RADDATZ, K., 1960: "Primicias de un corte estratigráfico en Carmona". ArchHisp 103-4 (2. ${ }^{a}$ época).

Celestino PÉREZ, S., 1992: "Cancho Roano. Un centro comercial de carácter político-religioso de influencia oriental. RStFen XVIII, 1. 19-50.

Celestino Pérez, S., y Jiménez Ávila, J., 1993: El Palacio-Santuario de Cancho Roano, IV. El sector Norte. Badajoz.

Celestino, S.; EnRíQueZ, J. J., y RoDrígueZ, A., 1992: "Paleoetnología del área extremeña" Paleoetnología de la Península Ibérica, Complutum 2-3. 311 ss.

Chaves Tristán, F., y De la BANDERA, M. L., 1988: "Excavación arqueológica en el Cortijo de Vico (Marchena, Sevilla), 1985". AnAAnd III. 1985. 372-379.

Del Amo Y DE LA Hera, M., 1978: “El Castañuelo. Un poblado céltico en la provincia de Huelva". HuelvaA IV. 299-340.

DOMERGUE, C., 1970: “Un témoignagne sur l'industrie minière et métallurgique du plomb dans la région d'Azuaga (Badajoz) pendant la guerre de Sertorius». CongNacA XIV. 608-625

- 1985: "Algunos aspectos de la explotación de las minas de la Hispania en la época republicana". Pyrenae. Crónica Arqueológica. 91-96.

- 1987: Catalogue des mines et fonderies antiques de la Péninsule Ibérique. Série Archéologique, VIII. Madrid. 2 vols.

Domínguez de la CONCHA, M. C., y García BlanCO, J., 1991: "La Tabla de las Cañas (Capilla, Badajoz). Apuntes preliminares". ExtrA II. 235-245.

Domínguez, C.; Cabrera, P., y Fernández, J., 1988: “Cerro de la Cabeza (Santiponce, Sevilla). NAHisp 30. 120-186.

ENRíQuez NAVASCUÉs, J. J., 1988: “Algunas cerámicas decoradas del Castillo de Alange (Badajoz)". HomSantos. Albacete.

Enríquez NAVASCuÉs, J. J., y RoDríguez DíAZ, A., 1985: Las piezas de oro de Segura de León y su entorno arqueológico. Mérida.

- 1988: "Campaña de urgencia en la Sierra de la Martela (Segura de León, Badajoz)". ExtrA I. 
Enríquez, J. J.; Rodríguez, A., y PAVón, I., E.p.: El Risco. Excavación de urgencia en Sierra de Fuentes (Cáceres). 1991 y 1993. Mérida.

ESCACENA CARRASCO, J. L., 1986: Cerámicas a torno pintadas andaluzas de la Segunda Edad del Hierro. Tesis Doctoral. Ed. microfichas. Universidad de Sevilla. Sevilla.

- 1987: "El poblamiento ibérico en el Bajo Guadalquivir". Iberos 1. Jaén, 1985. 273-298.

- 1989: "Los turdetanos o la recuperación de la identidad perdida". Tartessos. Sabadell. 433-476.

- 1992: "Indicadores étnicos en la Andalucía prerromana", Spal 1. 321-343.

- 1993: -De la muerte de Tartessos. Evidencias en el registro poblacional. Spal 2. 183 ss.

FERNÁNDEZ Avilés, A., 1958: "De orfebrería antigua hispana. Joyas de plata del Museo de Badajoz" RABM LXV. 569 ss.

FERnÁNDEZ, J. M.; SAUCEDA, M. I., y RODRÍGUEZ, A., 1988: "Los poblados calcolítico y prerromano de Los Castillejos (Fuente de Cantos, Badajoz). ExtrA I.

FERnÁNDEZ Jurado, J., 1986: "Fenicios y griegos en Huelva", HomSiret. Sevilla. 576 ss.

- 1987-a: "El poblamiento ibérico en Huelva". Iberos 1. Jaén. 315-326.

- 1987-b: "Tejada la Vieja: una ciudad protohistórica". HuelvaA IX.

- 1988-89: "Tartessos y Huelva". HuelvaA X-XI.

FERNÁNDEZ OCHOA, C. y otros, 1994: Sisapo I. Excavaciones arqueológicas en La Bienvenida, Almodóvar del Campo (Ciudad Real). Toledo.

Ferreira da Silva, A. C., y VARela Gomes, M. 1992: Proto-bistória de Portugal. Lisboa.

García y Bellido, A., 1945: España y los españoles hace dos mil años. Madrid, 1986. 9. ${ }^{a}$

- 1947: La España del siglo I de nuestra Era (según P. Mela y C. Plinio). Madrid, 1978. 3.

García y Bellido, M. P., 1991: "Las religiones orientales en la Península Ibérica: documentos numismáticos I-. AEspA 64. 37-81.

García Iglesias, L., 1971: "La Beturia, un problema geográfico de la Hispania Antigua". ArchEspA 44, 86-108.

González WAGNER, C., 1993: "Las estructuras del mundo tartésico". Los enigmas de Tarteso. Madrid. 103-116.

Guerrero AYuso, V. M., 1991: "Las ánforas del Palacio-Santuario de Cancho Roano (Badajoz). Un avance a su estudiom. RStFen XIX, 2.

Judice Gamito, T. , 1981: "A propósito do castro de Segovia (Elvas). Resistencia a Roma no Sudoeste peninsular. Historia 29. 32-43.

KNAPP, R. C., 1977: Aspects of the Roman Experience in Iberia: 206-100 BC., AnHispAnt IX.

LÓPEZ MELFRO, R., 1986: “Nueva evidencia sobre el culto de Ategina: el epígrafe de Bienvenida. Manifestaciones religiosas en la Lusitania. Cáceres. 83-112.

LÓPEZ, R.; SÁNCHEZ, J. L., y GARCíA, S., 1984: "El bronce de Alcántara. Una deditio del 104 a. C.". Gerión 2. 
LÓPEZ PALOMO, L. A., 1987: “Iberos y celtas en la penillanura de Los Pedroches (Córdoba). RAMadrid 69. 37-45.

LÓPEZ PARDO, F., 1990: "Sobre la función del edificio singular de Cancho Roano". Gerión, 8. 141-162.

LORRIO ALVARADO, A., 1988-89: “Cerámica gris orientalizante de la necrópolis de Medellín (Badajoz). Zephyrus XLI-XLII. 283-314.

- 1994: "El armamento de los celtas hispanos”. Los Celtas: Hispania y Europa. Madrid. 285 ss.

Luzón, J. M., y Ruiz, D., 1973: Las raíces de Córdoba. Estratigrafía de la Colina de los Quemados. Madrid.

MALUQUER DE MOTES, J., 1981: "EL Santuario protohistórico de Zalamea de la Serena (Badajoz)». En Maluquer de Motes, J., y Aubet Semmler, M. E.: Andalucía y Extremadura. PIP. Barcelona. 225-409.

Maluquer de Motes, J.; Celestino Pérez, S.; García, F., y Munill.a, G., 1986: El Santuario protobistórico de Zalamea de la Serena, Badajoz, III. 1983-1986. Barcelona.

MuRILlo REDONDO, J. F., 1993: “Poblamiento protohistórico y minería en el norte de la provincia de Córdoba-. HistAntAnd $\mathrm{I}$. Córdoba. 265 ss.

Olmos Romera, R., 1977: "El Sileno Simposiasta de Capilla (Badajoz). TrabPrHist 34. 371-388.

OrTIZ Romero, P., 1991: "Excavaciones y sondeos en los recintos de tipo torre de La Serena, Badajoz". ExtrA II 301-317.

- 1995: "Los recintos ciclópeos de La Serena. Usos (y abusos)". HomGil-Mascarell. ExtrA V.

Ortiz Romero, P., y Rodríguez DíAz, A., 1989: "Problemática general en torno a los recintos-torre de La Serena, Badajoz". CongNacA XIX. Castellón-Zaragoza.

PALOMAR LAPESA, M., 1957: La onomástica personal prelatina en la antigua Lusitania. Salamanca.

PAStor Muñoz, M., y PACHÓn ROMERO, J. A., 1992: Mirobriga. Excavaciones en el Cerro del Cabezo (Capilla, Badajoz). Mérida.

Pellicer Catalán, M., 1976-78: “Problemática general de los inicios de la iberización en Andalucía Occidental". Ampurias 38-40. 3-22.

- 1979-80: "Ensayo de periodización y cronología tartesia y turdetana". Habis 10-11. 307-334.

- 1983: "El yacimiento protohistórico de Quebrantahuesos". NAHisp 15. 55-185.

- 1993: "Crítica analítica de la arqueología tartesia y turdetana". Lengua y Cultura en la Hispania prerromana. Salamanca. 189-207

Pellicer Catalán, M., y Amores Carredano, F., 1985: "Protohistoria de Carmona. Los cortes estratigráficos CA 80-A y CA 80-B். NAHisp 22. 55-185. 
Pellicer, M.; Bendala, M., y EsCaCena, J. L., 1983: "El Cerro Macareno (Sevilla)». ExArqEsp 124.

Perdigones, L.; Muñoz, A., y PissanO, G., 1990: "La necrópolis fenicio-púnica de Cádiz. Siglos VI-IV". StPun 7. Roma.

Pereira MaiA, M. G., y Correa, J. A., 1985: "Inscripción en escritura tartésia (o del SO) hallada en Neves (Castro Verde, Baixo Alentexo) y su contexto arqueológico". Habis 16. 243 ss.

PÉrez Macías, A., 1987: Carta Arqueológica de los Picos de Aroche. Huelva.

- 1990: Castañuelo, los orígenes de la Beturia Céltica. Museo Arqueológico de Huelva. Huelva.

Rodríguez Díaz, A., 1986: Arqueología de Tierra de Barros. Mérida.

- 1987: El poblamiento prerromano en la Baja Extremadura. Tesis Doctoral. Inédita. Cáceres.

- 1989: "La Segunda Edad del Hierro en la Baja Extremadura: problemática y perspectivas en torno al poblamiento". Saguntum 22. 165-224.

- 1990: “Continuidad y ruptura cultural durante la Segunda Edad del Hierro en Extremadura". La Cultura Tartésica y Extremadura. Mérida. 127-162.

- 1991-a: La Ermita de Belén (Zafra, Badajoz). Campaña de 1987. Mérida.

- 1991-b: “Proyecto Hornachuelos (Ribera del Fresno, Badajoz): 1986-1990». ExtrA II. 283-300.

- 1993: "Sobre la periferia turdetana y la configuración diversa de la Beturia: célticos y túrdulos en el Guadiana Medio", Spal 2.

- 1994: "El Valle Medio del Guadiana, "espacio de frontera" en la protohistoria del Suroeste». Saguntum 27 y 28.

- 1995-a: “Territorios y etnias prerromanas en el Guadiana Medio: Aproximación arqueológica a la Beturia Túrdula". Célticos y Túrdulos: la Beturia. Mérida, 1994.

- 1955-b: "Extremadura prerromana". ExtraA IV. Mérida-Madrid.

- 1995-c: -El problema de la Beturia en el marco del poblamiento protohistórico del Guadiana Medio". Hom Gil-Mascarell. ExtrA V. Mérida-Cáceres.

Rodríguez Díaz, A., y Berrocal RANGel, L., 1988: "Materiales cerámicos de la Segunda Edad del Hierro del Cantamento de la Pepina (Fregenal de la Sierra, Badajoz). CUPAUAM 15. 215-252.

RODRÍGUEZ DíAZ, A., y ENRÍQUEZ NAVASCUÉs, J. J., 1992: “Necrópolis protohistóricas de Extremadura. CongArqIbérica. Las necrópolis. Madrid. 531-562

RODRÍGuez DíAZ, A., e IÑESTA MENA, J., 1984: "Las Dehesillas, un poblado prerromano en el término municipal de Higuera de Llerena, Badajoz)". Norba 5. 17-28.

Ruiz MatA, D., 1986: -Las cerámicas fenicias del Castillo de Doña Blanca (Puerto de Santa María, Cádiz)». Los Fenicios en la Península Ibérica. Barcelona. 241-263. 
- 1987: :La formación de la cultura turdetanan en la bahía de Cádiz a través del Castillo de Doña Blanca". Iberos. 299 ss.

SChulten, A., y Maluquer, J. (dir.), 1987: „Hispania Antigua según Pomponio Mela, Plinio el Viejo y Claudio Ptolomeon. FHA VII. Barcelona.

STYLOw, A. U., 1991: "El municipium Flavium V (...) de Azuaga (Badajoz) y la municipalización de la Baeturia Turdulorum". StHist IX. 11-27.

Tavares, C.; Soares, J.; BeiraO, C. M.; Ferrer, L., y Coelho-Soares, A., 1980-81: -Escavações arqueológicas no castelo de Alcácer do Sal (campanha de 1979)m. SetúbalA VI-VII. 149 ss.

UntermanN, J, 1965: "Elementos para un Atlas Antroponímico de la Hispania Antigua". BibPrHisp VIII. Madrid.

- 1985: "Lenguas y unidades políticas del Suroeste Hispánico en época prerromana. De Tartessos a Cervantes. Colonia. 1-40.

VALDÉS FeRnÁNDEZ, F., 1979: "Excavaciones en la Alcazaba de Badajoz. REstBadajoz XXXV-2. 337 ss. 